\title{
MERGERS AND ACQUISITIONS: EVIDENCE ON POST-ANNOUNCEMENT PERFORMANCE FROM CEE STOCK MARKETS
}

\author{
Adam ZAREMBA ${ }^{1}$, Michał PŁOTNICKI ${ }^{2}$ \\ ${ }^{1}$ Poznan University of Economics, al. Niepodleglosci 10, 61-876 Poznan, Poland \\ ${ }^{2}$ Warsaw School of Economics, al. Niepodleglosci 162, 02-554 Warsaw, Poland \\ E-mails: ${ }^{1}$ adam.zaremba@ue.poznan.pl (corresponding author); \\ ${ }^{2}$ michal.plotnicki@gmail.com
}

Received 23 March 2015, accepted 02 October 2015

\begin{abstract}
The paper re-examines the short-term and long-term performance following announcements of mergers and acquisitions. This is the first study that comprehensively explores this phenomenon in Central and Eastern European countries. We find strong evidence that announcement of a takeover creates value for both bidders and acquirers in the short run. Simultaneously, contrary to the stylized fact reported by a majority of U.S. based studies, after controlling for local value, size, and momentum factors the mergers and acquisitions do not destroy the value of the acquirers in the long term. The observations are important for corporate governance and portfolio management. The research is based on 109 deals in years 2001-2014. For the short-horizon event studies, we calculate average cumulative abnormal returns and we employ of the zero, index, and market models. For the long-run studies, we build equally and capitalization-weighted calendar-time portfolios and test their performances with CAPM, three-factor and four-factor models.
\end{abstract}

Keywords: event study, mergers and acquisitions, short-term performance, long-run performance, Central and Eastern Europe, stock market, abnormal returns.

JEL Classification: G11, G14, G34.

\section{Introduction}

Nowadays, the global business environment requires from its participants to constantly look for growth opportunities. This growth can be achieved either through organic or through external growth (Jayesh 2012). The latter can be achieved through mergers and acquisitions (M\&As), which Kumar and Paneerselvam (2009) defined as an attempt of the acquiring company to secure control of the target company and implement an operational strategy that would have the effect of increasing the value of both companies. As such, M\&As constitute an important and challenging field of research in the area of finance and strategy. Consequently, a number of empirical studies concerning miscellaneous features of M\&A, including M\&A activity and its trends, transactions' characteristics, as well as potential gains or losses related to acquisitions, have been developed. 
The intensity of M\&A effects cause these processes to directly affect the prices of common stocks of both the bidder and the target (Shah, Arora 2014). Some, such as Benoit et al. (2010), even claim that improvement of the share price is the primary purpose of the M\&A transactions.

There is a number of studies focusing on the stock returns after the announcement date. It is, however, worthwhile to mention, that the majority of these studies investigated the phenomenon within the developed markets, such as U.S. or Western European countries (Moeller et al. 2005; Andrade et al. 2001; Dutta, Jog 2009; Morck et al. 1990; Jensen, Ruback 1983; Jarrel et al. 1988; Bradley et al. 1988; Hackbarth, Morellec 2008; Gaughan 2005), while a number of studies involving the examination of emerging markets is very limited. Analogously, the research studies concerning Central and Eastern Europe are infrequent. Some of these very few studies were prepared by Uzunski (2011) and Bednarczyk et al. (2010), however, the latter examines specifically the energy sector. Such limitations, according to Ma et al. (2009), may result from lack of comprehensive databases in emerging markets, as well as relatively small economies of scale and scope in these market. The same authors notice that the theories explaining the M\&A characteristics may differ when comparing developed markets with the emerging ones. This was even more firmly indicated by Wong and Cheung (2009), who stated that the results of M\&A in the developed world are valid for the developed world, but are not valid for the developing world.

Further distinction shall be made when assessing the M\&A impact in the short term and in the long term. Stafford (2012) noticed that scores of studies discussing the M\&A influence on post-transaction stock performance relate to short-term effects, immediately surrounding announcement dates, while a substantially more limited number of studies examine the long-run post acquisition returns. The reason of such phenomenon may be explained by Agrawal et al. (1992) and Andrade et al. (2001), who claim that such approach assumes market efficiency and ability to digest almost immediately the full impact of the acquisition. On the other hand, this is not supported by behavioural theory of finance that suggests that markets are inefficient (Shleifer, Vishny 2003). Furthermore, Shleifer and Vishny (2003) promote the theory of stock-market-driven-acquisitions falling into the field of behavioural finance, according to which, stock market acquisitions are the response to market misvaluation.

The paper aims to contribute to global short- and long-horizon event studies of mergers and acquisitions on stock markets. The basic aim of this paper is to provide fresh-out of sample evidence on short-term and long-term abnormal-post merger performance.

For the short-horizon event studies, we use the average cumulative abnormal return (ACAR) approach, and measure abnormal returns with the zero model, index model, and market models. For the long-run studies, we build equally and capitalization-weighted calendar-time portfolios and test their performances with the CAPM, the three-factor model, and the four-factor model. The research is based on $109 \mathrm{M} \& \mathrm{~A}$ deals in CEE countries in years 2001-2014.

The principal findings can be summarized as follows. First, we document positive and significant abnormal returns on both the acquiring companies and the target companies 
in the first weeks following the transaction announcement. Second, we find no significant evidence of long-run negative abnormal returns of acquiring companies.

The structure of the paper is the following. In the next section, we discuss the data sources and research methods. Subsequently, the following part provides findings and discussion. Finally, the last section concludes the paper.

\section{Research design}

We investigate the issue of anomalous post-merger short- and long-term performance among companies from CEE markets for years 2001-2014. We test three distinct hypotheses. First, we examine whether stocks of acquirers are characterised by short-term abnormal returns. Second, we apply analogous tests to target companies. Finally, we study whether the long-run returns of acquiring firms are abnormally low.

\subsection{Data sources and preparation}

The study is based on stock-level data from Bloomberg and it is focused on merger and acquisition transactions in Central and Eastern European (CEE) countries. The precise understanding of CEE countries vary across the literature, so this study follows the OECD glossary, which defines CEE as Bulgaria, Croatia, the Czech Republic, Estonia, Hungary, Latvia, Lithuania, Poland, Romania, Slovakia and Slovenia. ${ }^{1}$ Nonetheless, due to the structure of the CEE stock market, most of transactions were conducted by Polish, Czech or Hungarian firms. In order to be included in a sample, both target and acquiring companies had to be listed on a CEE stock exchange when the transaction was announced, and both companies had to operate in one of the CEE countries. The cases in which the deal participants could not be unequivocally indicated were excluded. We used all the announced deals available in Bloomberg, which were purported to purchase a majority or minority stake, no matter what was the final result of the transaction attempt. Precisely, about $85 \%$ of our sample constitutes completed deals, $7 \%$ were terminated or the bidder withdrew an offer, and $8 \%$ of transactions are still pending and have not been finished. The basic timeframe was October 2001 - September 2014, however in the case of long term study we investigated the portfolios of M\&A stocks only for period April 2002 - June 2014. This shortened study period is due to availability constraints of necessary asset pricing factors for the CEE market. The sample excluded companies which were listed so short, that there was no sufficient time-series data to carry out the event studies. Finally, following the approach of Rouwenhorst (1999), De Moor and Sercu (2013), and Waszczuk (2014), the sample was manually screened in order to filter out any mistakes in the databases and suspicious records. Eventually, the sample encompassed 109 transaction announcements.

Our initial accounting and market data are collected in local currencies, however we agree with Liew and Vassalou (2000), and Bali et al. (2013) that comparisons using different currency units could be misleading. This is especially true in the CEE devel-

\footnotetext{
${ }^{1} \mathrm{http}: / /$ stats.oecd.org/glossary/detail.asp?ID=303.
} 
oping countries, where inflation and risk-free rates are sometimes very high and differ significantly across markets. Therefore, we follow the approach of Liu et al. (2011), Bekaert et al. (2007), or Brown et al. (2008), and denominate all data in euro to obtain polled international results. In order to be consistent with the euro approach, in the study excess returns are computed over the 1-month EURIBOR rate.

\subsection{Short-horizon event study}

To examine all hypotheses in this study, we employed a classical event study methodology, which was introduced by Fama et al. (1969) ${ }^{2}$. However, the precise approach differed for thr short- and long-term studies.

The short-term rates of returns, for both acquirers and target companies, were explored with the ACAR method. We began by calculating abnormal returns (ARs) for each day within 20 days after transaction announcement, including the day of the announcement. The daily AR was calculated as:

$$
A R_{i t}=R_{i t}-R_{E(i, t)}
$$

where $R_{i t}$ denotes stock $i$ return on day $t$, and $R_{(E(i, t))}$ is stock's $i$ expected return on day $t$. The econometric literature offers a wide range of expected return models, which additionally in recent years significantly gained on sophistication. Interesting reviews could be found for instance in papers of Campbell et al. (1996) or Kothari and Warner (2007). To make sure that our results are robust, we used three distinct expected-return models. The first one is a simple zero model, which assumes that the expected return on a given asset is 0 :

$$
R_{E(i, t)}=0 \text {. }
$$

The model is clearly far from theoretical purity, but its simplicity provides interesting information on price patterns. The second model is an index model. It assumes, that the expected return is equal to the return on an appropriate market index (benchmark):

$$
R_{E(i, t)}=R_{m, t}
$$

As a representation of CEE stock market, we employed the MSCI Eastern Europe ex. Russia Total Return EUR Index (MSCI EE). It is a broadly accepted benchmark for the CEE stocks and it is based on value-weighted euro-denominated returns of the largest and most-liquid CEE companies.

Finally, the last model is a classical market model:

$$
\begin{gathered}
R_{E(i, t)}=\alpha_{i}+\beta_{i} R_{m, t}+\varepsilon_{i, t}, \\
E\left(\varepsilon_{i, t 0}\right)=0, \operatorname{var}\left(\varepsilon_{i, t 0}\right)=\sigma_{\varepsilon}^{2},
\end{gathered}
$$

where $R_{E(i, t)}$ and $R_{m t}$ are the period-t returns on a security and the market portfolio, $\varepsilon_{i . t}$ is the zero mean disturbance term and $\alpha_{i}, \beta_{i}$ and $\sigma_{\varepsilon^{\wedge} 2}$ are the parameters of the market

2 An up-to-date discussion of event studies' methodologies could be found, for instance, in MacKinlay (1997), Campbell et al. (1996), Cochrane (2005), or Kothari and Warner (2007). 
model. Once again, the return on market portfolio was proxied by MSCI EE index. The model parameters were estimated using Ordinary Least Squares (OLS) regression and the $t$-statistics are estimated using bootstrap standard errors, in order to avoid any distributional assumption. Our parameter estimation window was 120 trading days long (about 6 months) and it was lagged 20 days in order to avoid any impact of the investigated event. In other words, we estimated parameters based on returns on trading days from $t-140$ to $t-21$.

It is worth to note, that although we are aware that our approach do not account for value (Stattman 1980; Rosenberg et al. 1985), size (Banz 1981), or momentum (Jegadeesh, Titman 1993) effects, which to some extend influence asset pricing in the Central and Eastern Europe (Cakici et al. 2013; Zaremba 2015; Zaremba, Konieczka 2015), but daily data on respective asset pricing factors are not available for the CEE markets.

After computing daily ARs based on expected return models, we proceeded with timeseries aggregation, so as to obtain cumulative abnormal returns (CARs):

$$
\mathrm{CAR}_{i}=\sum_{t=1}^{T} \mathrm{AR}_{i, t}
$$

and then we averaged CARs cross-sectionally for all the stocks in the sample, in order to obtain average cumulative abnormal returns (ACARs):

$$
\operatorname{ACAR}=\frac{1}{N} \sum_{i=1}^{N} \mathrm{CAR}_{i},
$$

where $N$ is the number of stocks in the sample. The null hypothesis that ACARs are not significantly different from zero is confronted with an alternative hypothesis that ACARs actually differ from zero. We verify our hypothesis with parametric ( $t$-statistic and normal distribution) tests, in line with methods proposed by Kothari and Warner (2007: 11).

\subsection{Long-horizon event study}

The second event-study approach, which was chosen particularly for the long-run postmerger performance, is the calendar-time portfolio method. The calendar-time portfolio approach for detecting long-run abnormal returns was introduced by Jaffe (1974) and Mandelker (1974), and then strongly recommended by Fama (1998). This method is regarded as appropriate for long-term event studies because it minimizes the issue of parameters instability over time. It also mimics investor's perspective. We constructed three types of portfolios with 1-, 2-, and 3-year holding periods respectively $(12,24$, and 36 months). The acquirers' stocks were included in the portfolios at the end of the month during which the company announced the transaction, and excluded after 1, 2 or 3 years $(12,24$, or 36 months). The portfolio returns were calculated in both equally and capitalization-weighted approaches, in order to make sure of the robustness of results. To draw statistical inferences, we computed excess returns by subtracting cumulated monthly risk-free rates (1-month EURIBOR bid rate). 
The post-merger portfolio excess returns were finally tested against three distinct asset pricing models. The first one is the classical Capital Asset Pricing Model (Sharpe 1964). The model assumes that asset returns depend only on the market portfolio and is described by a regression equation below:

$$
R_{i, t}=\alpha_{i}+R_{f, t}+\beta_{r m, i} \cdot\left(R_{m t}-R_{f, t}\right)+\varepsilon_{i, t},
$$

where $R_{i, t}, R_{m, t}$ and $R_{f, t}$ are returns on the analyzed asset i, market portfolio and risk-free returns at time $t$, and $\alpha_{i}$, and $\beta_{r m, I}$ are regression parameters. The $\alpha_{i}$ intercept measures the average abnormal return (so called Jensen-alpha).

The second model is the Fama-French three factor model (Fama, French 1993):

$$
R_{i, t}=\alpha_{i}+R_{f, t}+\beta_{r m, i} \cdot\left(R_{m, t}-R_{f, t}\right)+\beta_{S M B} \cdot S M B_{t}+\beta_{H M L} \cdot H M L_{t}+\varepsilon_{i, t},
$$

where $\beta_{r m, i}, \beta_{S M B, i}, \beta_{H M L, i}$, and $\alpha_{i}$ ere the estimated parameters of the model. $\beta_{r m, i}$ is analogical to the CAPM beta, but it is not equal to it. The $\beta_{S M B, i}, \beta_{H M L, i}$ are exposed to $S M B_{t}$ (small minus big) and $H M L_{t}$ (high minus low) risk factors, which denote returns from zero-cost arbitrage portfolios. $S M B_{t}$ is the difference in returns on diversified portfolios of small and large caps at time $t$, while $H M L_{t}$ is in general difference in returns on portfolios of diversified value (high B/V) and growth (low B/V) stocks. In other words, $S M B$ and $H M L$ are returns on zero-cost market-neutral long/short portfolios formed based on size and value characteristics.

The third model is the four-factor model, which was originally introduced by Carhart (1997) and its corresponding regression equation is:

$$
\begin{aligned}
& R_{i, t}=\alpha_{i}+R_{f, t}+\beta_{r m, i} \cdot\left(R_{m, t}-R_{f, t}\right)+\beta_{S M B, i} \cdot S M B_{t}+ \\
& \beta_{H M L, i} \cdot H M L_{t}+\beta_{W M L, i} \cdot W M L_{t}+\varepsilon_{i, t} .
\end{aligned}
$$

The model additionally incorporates the momentum returns measured by returns on socalled winner and loser portfolios, which were used in the initial studies of this anomaly (Jegadeesh, Titman 1993). The $W M L_{, t}$ (winners minus losers) denotes the difference between returns on diversified winner and loser portfolios over the previous year ${ }^{3}$.

All the regression models are based on monthly time-series. The models are estimated using OLS regressions and, again, the $t$-statistics are estimated using bootstrap standard errors, in order to avoid any distributional assumption. The returns on asset pricing factors for the CEE market are computed according to procedures described in Zaremba (2015) and comes from Adam Zaremba's website ${ }^{4}$. In the case of long-run studies, our null hypothesis is that the alpha intercept is not statistically different from zero, and the alternative hypothesis states that it is actually different from zero.

\footnotetext{
${ }^{3}$ The importance of the value, size, and momentum effects as cross-sectional determinants of expected returns in the countries of Central and Eastern Europe was discussed by, among others, Waszczuk (2013) and Zaremba (2015). Furthermore, the applicability of the multifactor models, that are used in this study, in the CEE region was advocated by for example by Cakici et al. (2013), Zaremba (2015), and Hanauer and Linhart (2015).
}

${ }^{4} \mathrm{http}: / /$ adamzaremba.pl/downloadable-data/. 


\section{Research results and discussion}

In this section we discuss the research results. We first focus on the short-term returns on acquirers and targets, and next we explore the long-run performance of acquiring companies.

\subsection{Short-term abnormal returns}

The Table 1 reports the abnormal returns on acquiring companies during the first 20 business days following the transaction announcement. The first market reaction seems to be positive. On the announcement day the ACARs are equal $0.21-0.40 \%$, depending on the model used. On the next first and second day after the announcement the abnormal returns still increase. In cases of all three models used, the ACARs exceed $2 \%$ and are statistically significant. Nonetheless, what is somehow interesting is the fact, that over forthcoming weeks some of the abnormal returns become obliterated. Eventually, on the $20^{\text {th }}$ business day after the merger or acquisition announcement the abnormal returns decrease to $1.37 \%$ for the market model and $1.66 \%$ for the index model and are no longer statistically significant.

The Figure 1 additionally plots the abnormal returns from all three models on the graph. However, the precise pattern of the cumulative returns (particularly the decrease around the $13^{\text {th }}$ day) should be taken with a pinch of salt. The variability may be a result of a small sample bias.

Positive cumulative abnormal returns were experienced also by Uzunski (2011) in his research dedicated to Central and Eastern Europe and assessing the performance of the acquirers in short-term horizon after the merger announcement. However, in the global context, the results of the respective studies referring to the developed economies are fairly inconsistent (Hassan et al. 2007), mainly referring to the developed markets.

Table 1. Short-term abnormal returns on acquiring companies

\begin{tabular}{|c|c|c|c|c|c|c|c|c|}
\hline $\mathrm{T}$ & 0 & 1 & 2 & 3 & 5 & 10 & 15 & 20 \\
\hline \multicolumn{9}{|c|}{ Zero model } \\
\hline \multirow[t]{2}{*}{ ACAR } & 0.40 & 1.64 & 2.27 & 2.36 & 2.29 & 2.83 & 2.42 & 2.88 \\
\hline & $(1.10)$ & $(3.02)$ & $(3.58)$ & $(3.52)$ & $(3.07)$ & $(3.11)$ & $(2.07)$ & $(2.26)$ \\
\hline \multicolumn{9}{|c|}{ Index model } \\
\hline \multirow[t]{2}{*}{ ACAR } & 0.27 & 1.47 & 2.01 & 2.00 & 2.03 & 2.55 & 2.11 & 1.66 \\
\hline & $(0.74)$ & $(2.80)$ & $(3.30)$ & $(3.10)$ & $(2.84)$ & $(2.96)$ & $(1.90)$ & (1.38) \\
\hline \multicolumn{9}{|c|}{ Market model } \\
\hline \multirow[t]{2}{*}{ ACAR } & 0.21 & 1.54 & 2.21 & 2.18 & 1.97 & 2.63 & 1.86 & 1.37 \\
\hline & $(0.58)$ & $(2.99)$ & $(3.67)$ & $(3.46)$ & $(2.82)$ & $(3.11)$ & $(1.70)$ & $(1.15)$ \\
\hline
\end{tabular}

Notes: The table reports average cumulative abnormal returns on acquirers in the post-announcement period of 20 business days according to three models of expected returns: zero model, index model, and market model. The numbers in brackets denote test statistics. Source: authors' elaborations based on data from Bloomberg. 


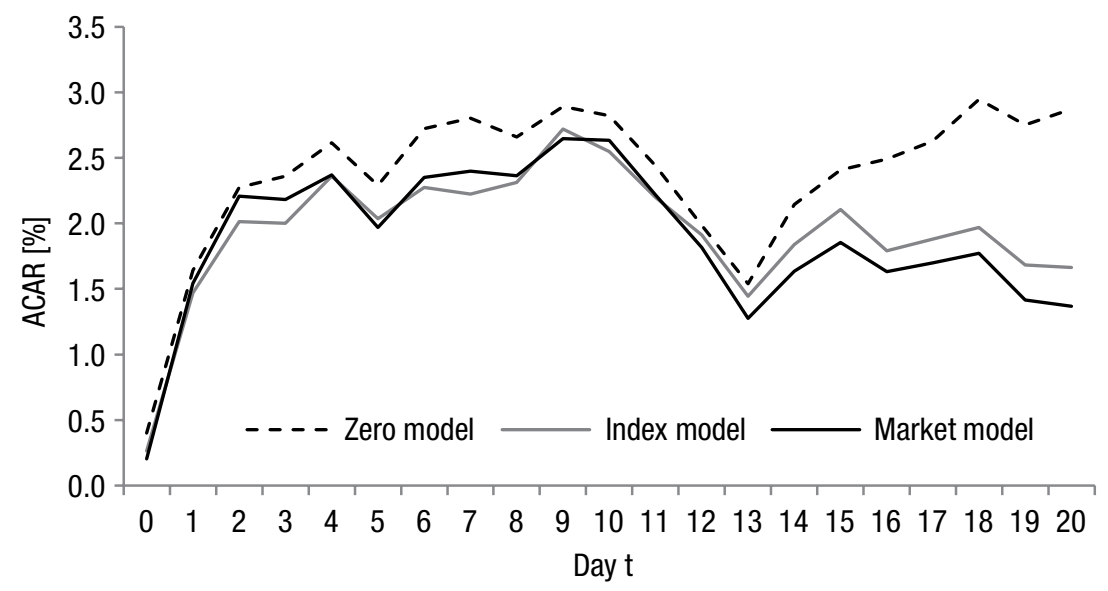

Fig. 1. Short-term abnormal returns on acquiring companies

Notes: The figure presents average cumulative abnormal returns on acquirers in the post-announcement period of 20 business days according to three models of expected returns: zero model, index model, and market model. Source: authors' elaborations based on data from Bloomberg.

A number of researches has evidenced a statistically positive cumulative abnormal return in the short-term, while also a substantial number of analysis has reported negative respective returns. More consistent results relate to the emerging markets, mainly Asian ones, when, e.g., Ma et al. (2009), Pangarkar and Lie (2004) and Vaziri (2011) have documented positive cumulative abnormal returns in the performance of the acquirers in the short-run.

The Table 2 depicts the post-merger short-term abnormal performance of the target companies during the first 20 post-announcement business days. At first sight the outcomes of the event study resemble the return patterns of the acquiring companies. However, the magnitude and statistical significance of the outperformance seems to be stronger. First, even on the announcement day the returns are positive, statistically significant and equal $0.72-0.90 \%$. Next, they steadily rise and remain statistically significant through the whole observation period. The abnormal returns in the market model on the $20^{\text {th }}$ day are equal $2.88 \%$.

The graphical examination of the post-merger performance of target companies (Fig. 2) generally confirms the results from the Table 2 . The abnormal returns increase steadily during whole observation period. This return pattern seems to differ from the performance of acquirers, in the case of which the anomalous returns seems to begin to fade around the $10^{\text {th }}$ day after announcement.

Such results are consistent with a number of other studies examining the impact of M\&As on the targets' stocks performance, however, one can find also studies with conflicting conclusions, such as Chakraborty (2010). Nevertheless, in light of the Gersdorff and Bacon (2009) observation indicating that a merger or acquisition can be defined as a combination of two firms where the bidder typically pays a premium related to synergies 
Table 2. Short-term abnormal returns on target companies

\begin{tabular}{cccccccccc}
\hline & 0 & 1 & 2 & 3 & 5 & 10 & 15 & 20 \\
\hline \multicolumn{7}{c}{ Zero model } \\
\hline ACAR & 0.90 & 1.48 & 1.80 & 2.17 & 2.36 & 2.78 & 3.93 & 4.49 \\
\hline & $(2.29)$ & $(2.54)$ & $(2.65)$ & $(2.94)$ & $(2.76)$ & $(2.56)$ & $(3.12)$ & $(3.26)$ \\
\hline ACAR & 0.79 & 1.30 & 1.57 & 1.77 & 2.09 & 2.59 & 3.80 & 3.67 \\
\hline & $(2.15)$ & $(2.35)$ & $(2.40)$ & $(2.49)$ & $(2.51)$ & $(2.39)$ & $(3.00)$ & $(2.66)$ \\
\hline \multicolumn{7}{c}{ Index model } \\
\hline ACAR & 0.72 & 1.23 & 1.46 & 1.67 & 1.76 & 1.99 & 2.87 & 2.88 \\
\hline & $(1.94)$ & $(2.23)$ & $(2.26)$ & $(2.38)$ & $(2.16)$ & $(1.89)$ & $(2.36)$ & $(2.16)$ \\
\hline
\end{tabular}

Notes: The table reports average cumulative abnormal returns on targets in the post-announcement period of 20 business days according to three models of expected returns: zero model, index model, and market model. The numbers in brackets denote test statistics. Source: authors' elaborations based on data from Bloomberg.

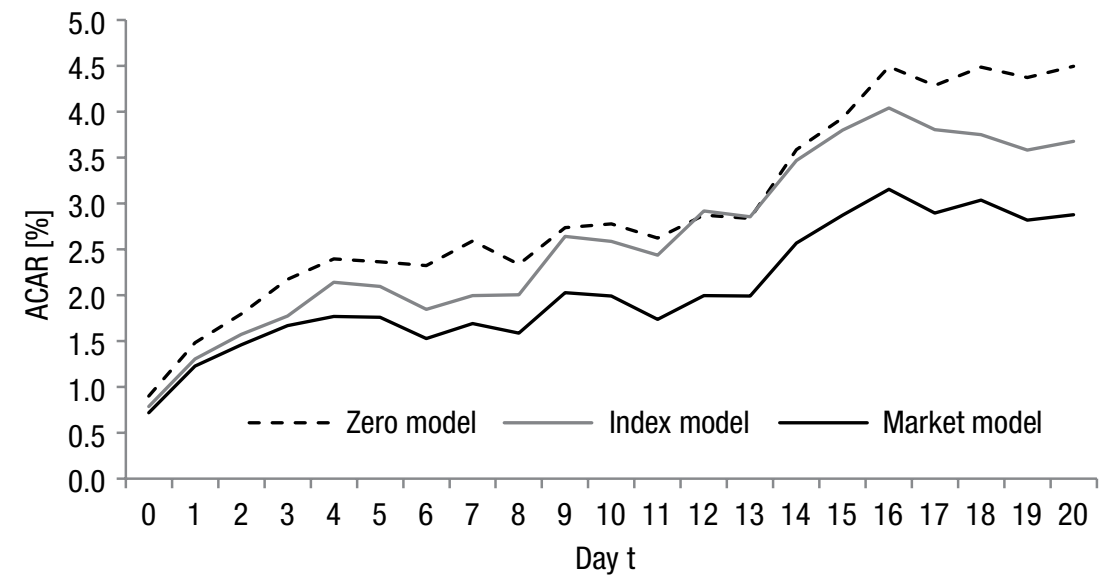

Fig. 2. Short-term abnormal returns on target companies

Notes: The figure presents average cumulative abnormal returns on targets in the post-announcement period of 20 business days according to three models of expected returns: zero model, index model, and market model. Source: authors' elaborations based on data from Bloomberg.

involved, it is often claimed that the shareholders of target firms are clearly winners in the M\&A process and all the gains from the merger process accrues almost entirely to the shareholders of the target firm (Andrade et al. 2001).

To sum up, the above presented outcomes basically support the hypothesis of positive abnormal short-term returns. Both acquirers and targets are characterized by abnormal and statistically significant rates of return in the first week following the M\&A transaction announcement. 


\subsection{Long-run abnormal returns}

The Figures 3-4 show the cumulative performance of respectively equally and capitalization-weighted portfolios of stocks of acquiring companies. The three timeframe approaches (12, 24, and 36 months) are presented and compared with the performance of the MSCI EE. At first sight, no significant abnormal returns are visible. All the strate-

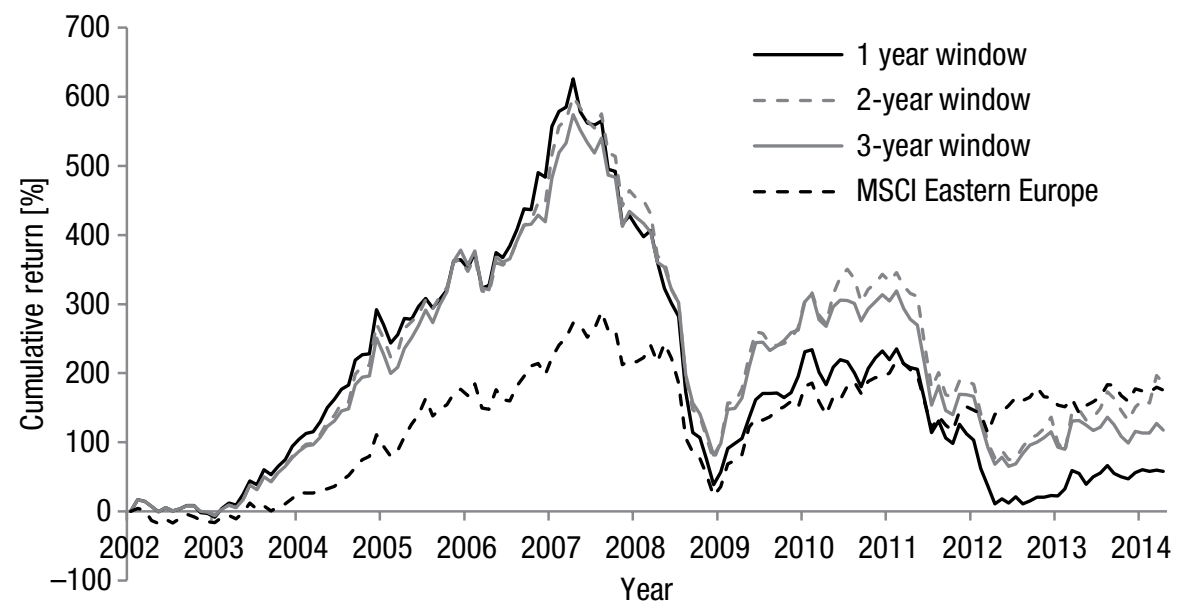

Fig. 3. Long-run cumulative returns on equally weighted portfolios of acquiring companies

Notes: The figure presents long-run cumulative returns on acquirers. The three types of equally weighted portfolios include companies which announced M\&A transactions no longer than 12, 24, and 36 months earlier respectively. The returns are compared with the MSCI Eastern Europe ex. Russia Total Return EUR Index. Source: authors' elaborations based on data from Bloomberg.

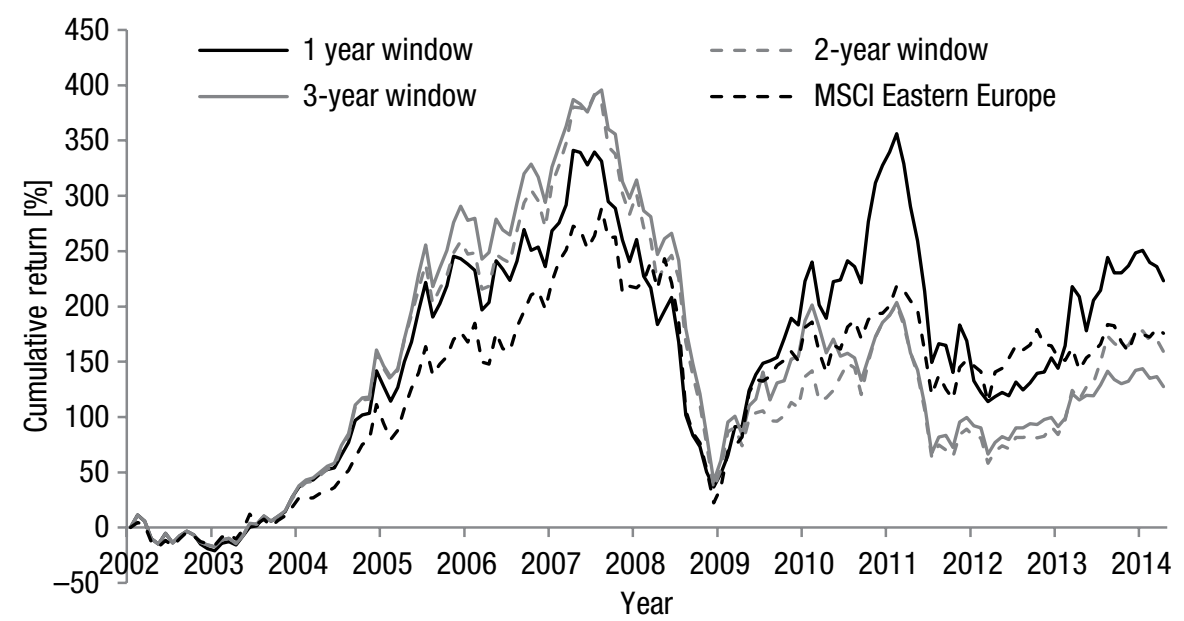

Fig. 4. Long-run cumulative returns on capitalization-weighted portfolios of acquiring companies

Notes: The figure presents long-run cumulative returns on acquirers. The three types of capitalizationweighted portfolios include companies which announced M\&A transactions no longer than 12, 24, and 36 months earlier respectively. The returns are compared with the MSCI Eastern Europe ex. Russia Total Return EUR Index. Source: authors' elaborations based on data from Bloomberg. 
gies perform worse than the broad portfolio the Eastern European stocks, but the size of the underperformance is rather modest. The only exception is the 12-month equallyweighted portfolio, which delivers slightly higher returns than MSCI EE. Furthermore, the merger-based portfolios seem to be more risky in terms of standard deviation than MSCI EE, and it is particularly true in the case of equal weighting. The Figures 3-4 reveal significant price increases followed by sizeable drawdowns, which appear to be larger than in the case of MSCI EE.

Table 3 provides some formal statistical inferences on the long-run post-merger performance. Basically, the results indicate that the acquiring companies underperform, but the scale of the performance is low and not statistically significant. Thus, our results do not support the underperformance hypothesis, but are far from being conclusive.

The intercepts from CAPM model are mostly negative, with the exception of 24-months equally weighted portfolio and 12-months capitalization-weighted portfolios. All the portfolios exhibit significant exposure to market risk and the market beta is close to one. The intercepts from the four-factor model are also negative and non-significant, and range from $-0.05 \%$ to $-0.74 \%$ monthly. Actually, inclusion of the additional pricing factors does not alter the landscape meaningfully. The SMB and HML factors are mostly insignificant, which suggest that acquiring companies do not have any value or size tilt. Finally, the four-factor model alphas are also negative and range from $-0.11 \%$ to $-0.71 \%$. Furthermore, they lack statistical significance. Similarly as in the case of the three-factor model, the WML factor is insignificant, so the momentum effect does not strongly impact the post-merger performance ${ }^{5}$.

Table 3. Long-term performance of acquiring companies

\begin{tabular}{|c|c|c|c|c|c|c|}
\hline & \multicolumn{3}{|c|}{ Equally weighted portfolios } & \multicolumn{3}{|c|}{ Capitalization-weighted portfolios } \\
\hline & 12 months & 24 months & 36 months & 12 months & 24 months & 36 months \\
\hline \multicolumn{7}{|c|}{ Basic statistics - excess returns } \\
\hline \multirow[t]{2}{*}{ Mean } & 0.53 & 0.93 & 0.69 & 0.95 & 0.79 & 0.69 \\
\hline & $(0.74)$ & $(1.30)$ & $(1.04)$ & $(1.46)$ & $(1.24)$ & $(1.10)$ \\
\hline St. dev. & 8.62 & 8.67 & 8.03 & 7.92 & 7.68 & 7.63 \\
\hline \multicolumn{7}{|c|}{$C A P M$} \\
\hline \multirow[t]{2}{*}{$\alpha$} & -0.34 & 0.05 & -0.16 & 0.12 & -0.06 & -0.16 \\
\hline & $(-0.75)$ & $(0.11)$ & $(-0.43)$ & $(0.32)$ & $(-0.19)$ & $(-0.48)$ \\
\hline \multirow[t]{2}{*}{ Mkt-Rf } & 1.00 & 1.01 & 0.98 & 0.96 & 0.98 & 0.98 \\
\hline & $(14.86)$ & $(15.07)$ & $(17.37)$ & $(16.56)$ & $(19.84)$ & $(20.35)$ \\
\hline
\end{tabular}

\footnotetext{
${ }^{5}$ To test the robustness of this results, wa also re-examined the long-run performance of the aquirers within the subsample of the successful mergers and aqusitions. We found no qualitative differences in the outcomes. For the brevity, we do not report the results in this paper.
} 
End of Table 3

\begin{tabular}{|c|c|c|c|c|c|c|}
\hline & \multicolumn{3}{|c|}{ Equally weighted portfolios } & \multicolumn{3}{|c|}{ Capitalization-weighted portfolios } \\
\hline & 12 months & 24 months & 36 months & 12 months & 24 months & 36 months \\
\hline \multicolumn{7}{|c|}{ Three-factor model } \\
\hline \multirow[t]{2}{*}{$\alpha$} & -0.74 & -0.26 & -0.40 & -0.05 & -0.18 & -0.36 \\
\hline & $(-1.53)$ & $(-0.54)$ & $(-0.97)$ & $(-0.12)$ & $(-0.49)$ & $(-1.04)$ \\
\hline \multirow[t]{2}{*}{ Mkt-Rf } & 1.06 & 1.05 & 1.02 & 0.97 & 0.98 & 0.99 \\
\hline & (14.99) & $(14.70)$ & $(16.88)$ & $(15.69)$ & $(18.62)$ & (19.43) \\
\hline \multirow[t]{2}{*}{ SMB } & 0.28 & 0.15 & 0.15 & 0.01 & -0.02 & -0.01 \\
\hline & $(2.31)$ & $(1.22)$ & $(1.47)$ & $(0.14)$ & $(-0.26)$ & $(-0.14)$ \\
\hline \multirow[t]{2}{*}{ HML } & 0.18 & 0.17 & 0.11 & 0.13 & 0.10 & 0.16 \\
\hline & $(1.59)$ & $(1.55)$ & (1.18) & (1.33) & $(1.21)$ & $(2.06)$ \\
\hline \multicolumn{7}{|c|}{ Four-factor model } \\
\hline \multirow[t]{2}{*}{$\alpha$} & -0.71 & -0.14 & -0.35 & -0.16 & -0.11 & -0.30 \\
\hline & $(-1.34)$ & $(-0.26)$ & $(-0.79)$ & $(-0.34)$ & $(-0.28)$ & $(-0.78)$ \\
\hline \multirow[t]{2}{*}{ Mkt-Rf } & 1.06 & 1.04 & 1.02 & 0.98 & 0.98 & 0.98 \\
\hline & (14.30) & (13.91) & (16.08) & (15.18) & (17.70) & (18.47) \\
\hline \multirow[t]{2}{*}{ SMB } & 0.29 & 0.16 & 0.16 & 0.01 & -0.02 & -0.01 \\
\hline & $(2.31)$ & $(1.25)$ & (1.47) & $(0.10)$ & $(-0.24)$ & $(-0.11)$ \\
\hline \multirow[t]{2}{*}{ HML } & 0.17 & 0.14 & 0.10 & 0.16 & 0.08 & 0.15 \\
\hline & $(1.32)$ & (1.06) & $(0.91)$ & $(1.45)$ & $(0.86)$ & (1.60) \\
\hline \multirow[t]{2}{*}{ WML } & -0.01 & -0.06 & -0.02 & 0.05 & -0.03 & -0.03 \\
\hline & $(-0.14)$ & $(-0.60)$ & $(-0.25)$ & $(0.59)$ & $(-0.42)$ & $(-0.41)$ \\
\hline
\end{tabular}

Notes: The table reports the long-run performance of acquiring companies. The three types of capitalization-weighted portfolios and three types of capitalization-weighted portfolios include companies which announced M\&A transactions no longer than 12, 24, and 36 months earlier respectively. The asset pricing models are described in details in the research methods section. Mkt- $\mathrm{Rf}$ is a market risk factor, SMB is small minus big, HML is high minus low, WML is winner minus losers, and $\alpha$ is an intercept from a given model. The numbers in brackets denote test statistics. Source: authors' elaborations based on data from Bloomberg.

Summing up, our results generally do not support the hypothesis of the long-run underperformance of the acquiring companies. Comparing these results to the literature, which is mainly based on U.S. data, it is worthwhile to mention, that majority of studies concerning the developed markets experience negative abnormal returns, however, unlike the outcome of the hereby study, these are usually significant (Dutta, Jog 2009). 


\section{Conclusions}

Our results show that the positive abnormal returns are decreasing while extending the time window. Simultaneously, the target companies generate significant positive abnormal returns in the short-run, what may support the observation coming from a number of other studies claiming that it is not the shareholder of the bidder, but it is the shareholder of the target who gain on the M\&A process.

Our results have a few important both theoretical and practical implications. First, the stylized fact reported by a majority of U.S. based studies that conclude that acquiring firms show negative long-term abnormal performance should be viewed with caution. After controlling for value, size and momentum effects in local markets, we find no convincing evidence of long-term underperformance. In other words, the apparent abnormal returns (as documented in previous studies) may rather a result of measurement problems rather than mispricing. Second, lack of any evidence of the long-term value destruction following of acquirers is an important observation for corporate governance and management. Finally, the documented short term-value creation of both bidders and acquirers is valuable information for stock market investors. It proves that an eventdriven strategy based on M\&A deals may be successfully implemented in quantitatively managed portfolios with a regional focus.

However, our research findings have a few important limitations. First, we do not account for limited liquidity and transaction costs, which tend to be higher in emerging markets, especially across the small and tiny companies. Second, we do not take into account any investment and capital flow restrictions within the investigated countries. However, these are rather marginal, as all countries in our sample are EU members. Third, the period we study (2002-2014) may be regarded as relatively short and additionally unique, as it includes the Global Financial Crisis. Nonetheless, the longer time-series for the CEE markets are hardly available.

Furthermore, the event study methodology, as described inter alia by Bruner (2004), is not the only one used for determining the success of mergers and acquisitions. One of them, next to surveys and case studies, is also the accounting study methodology. Combination of the event study and accounting study methodologies could bring more comprehensive explanations regarding the actual value created by the M\&A decisions for the shareholders.

\section{Acknowledgements}

This paper is a part of the project no. 2013/09/B/HS4/01335 financed by the National Science Centre of Poland.

\section{References}

Agrawal, A.; Jaffe, J. F.; Mandelker, G. N. 1992. The post-merger performance of acquiring firms: a re-examination of an anomaly, Journal of Finance 67: 1605-1621.

http://dx.doi.org/10.2307/2328956 
Andrade, G.; Mitchell, M.; Stafford, E. 2001. New evidence and perspectives on mergers, Journal of Economic Perspectives 15(2): 103-120. http://dx.doi.org/10.1257/jep.15.2.103

Bali, C.; Cakici, N.; Fabozzi, F. 2013. Book-to-market and the cross-section of expected stock returns in international stock markets, Journal of Portfolio Management 39: 101-115.

http://dx.doi.org/10.3905/jpm.2013.39.2.101

Banz, R. W. 1981. The relation between return and market value of common stocks, Journal of Financial Economics 9: 3-18. http://dx.doi.org/10.1016/0304-405x(81)90018-0

Bednarczyk, T. P.; Schiereck, D.; Walter, H. N. 2010. Cross-border acquisitions and shareholder wealth: evidence from the energy and industry in Central and Eastern Europe, Journal for East European Management Studies 15: 106-127.

Bekaert, G.; Harvey, C.; Lundblad, C. 2007. Liquidity and expected returns: lessons from emerging markets, Review of Financial Studies 20: 1783-1831. http://dx.doi.org/10.1093/rfs/hhm030

Benoit, V. C.; Xavier, B.; Alain, F. 2010. Takeovers and bidders' return determinants on announcement date, Journal of Applied Business and Economics 11(1): 89-104.

Bradley, M; Desai, A.; Kim, E. H. 1988. Synergistic gains from corporate acquisitions and their division between the stockholders of target and acquiring firms, Journal of Financial Economics 21(1): 3-40. http://dx.doi.org/10.1016/0304-405x(88)90030-x

Brown, A.; Du, D. Y.; Rhee, S. G.; Zhang, L. 2008. The returns to value and momentum in Asian markets, Emerging Markets Review 9: 79-88. http://dx.doi.org/10.1016/j.ememar.2008.02.001

Bruner, R. F. 2004. Applied mergers and acquisitions. New York: John Wiley \& Sons.

Cakici, N.; Fabozzi, F. J.; Tan, S. 2013. Size, value, and momentum in emerging market stock returns, Emerging Markets Review 16: 46-65. http://dx.org/10.1016/j.ememar.2013.03.001

Campbell, J. Y.; Lo, A. W.; MacKinlay, A. C. 1996. The econometrics of financial markets. Princeton: Princeton University Press.

Carhart, M. M. 1997. On persistence in mutual fund performance, Journal of Finance 52: 57-82. http://dx.doi.org/10.1111/j.1540-6261.1997.tb03808.x

Chakraborty, M. 2010. The wealth effects of takeover announcement for firms in the financial services sector in India, Journal of Emerging Market Finance 9(2): 100-227.

http://dx.doi.org/10.1177/097265271000900204

Cochrane, J. H. 2005. Asset pricing. Princeton: Princeton University Press.

De Moor, L.; Sercu, P. 2013. The smallest firm effect: an international study, Journal of International Money and Finance 32: 129-155.http://dx.doi.org/10.2139/ssrn.1966998

Dutta, S.; Jog, V. 2009. The long-term performance of acquiring firms: a re-examination of an anomaly, Journal of Banking and Finance 33: 1400-1412. http://dx.doi.org/10.2139/ssrn.989677

Fama, E. F. 1998. Market efficiency, long-term returns, and behavioral finance, Journal of Financial Economics 49: 283-306. http://dx.doi.org/10.1016/S0304-405X(98)00026-9

Fama, E. F.; Fisher, L.; Jensen, M. C.; Roll, R. 1969. The adjustment of stock prices to new information, International Economic Review 10(1): 1-21. http://dx.doi.org/10.2307/2525569

Fama, E. F.; French, K. R. 1993. Common risk factors in the returns on stocks and bonds, Journal of Financial Economics 33: 3-56. http://dx.doi.org/10.1016/0304-405x(93)90023-5

Gaughan, P. A. 2005. Mergers: what can go wrong and how to prevent it. Hoboken, NJ: John Wiley \& Sons.

Gersdorff, N. V.; Bacon, D. F. 2009. U.S. mergers and acquisitions: a test of market efficiency, Journal of Finance and Accountancy 1(8): 1-8.

Hackbarth, D.; Morellec, E. 2008. Stock returns in mergers and acquisitions, The Journal of Finance 63(3): 1213-1252. http://dx.doi.org/10.1111/j.1540-6261.2008.01356.x 
Hanauer, M. X.; Linhart, M. 2015. Size, value, and momentum in emerging market stock returns: integrated or segmented pricing? Asia-Pacific Journal of Financial Studies 44(2): 175-214. http://dx.doi.org/10.1111/ajfs.12086

Hassan, M.; Patro, K. P.; Tuckman, H.; Wang, X. 2007. Do mergers and acquisitions create shareholder wealth in the pharmaceutical industry?, International Journal of Pharmaceutical and Healthcare Marketing 1(1): 55-78. http://dx.doi.org/10.1108/17506120710740289

Jaffe, J. F. 1974. Special information and insider trading, Journal of Business 47: 410-428. http://dx.doi.org/10.1086/295655

Jarrel, G.; Brickley, J. A.; Netter, J. M. 1988. The market for corporate control: the empirical evidence since 1980, Journal of Economic Perspectives 2(1): 49-68.

http://dx.doi.org/10.1257/jep.2.1.49

Jayesh, C. N. 2012. Why do mergers and acquisitions quite often fail?, Advances in Management 5(5): $21-28$.

Jegadeesh, N.; Titman, S. 1993. Returns to buying winners and selling losers: implications for stock market efficiency, Journal of Finance 48(1): 65-91. http://dx.doi.org/10.2307/2328882.

Jensen, M. C.; Ruback, R. S. 1983. The market for corporate control: the scientific evidence, Journal of Financial Economics 11: 5-50. http://dx.doi.org/10.1016/0304-405X(83)90004-1

Kothari, S. P.; Warner, J. B. 2007. Econometrics of event studies, in B. Espen Eckbo (Ed.). Handbook of Corporate Finance. Amsterdam: Elsevier/North-Holland.

Kumar, R.; Paneerselvam, S. 2009. Mergers, acquisitions and wealth creation: a comparative study in the Indian context, IIMB Management Review 21(3): 222-244.

Liew, J.; Vassalou, M. 2000. Can book-to-market, size and momentum be risk factors that predict economic growth?, Journal of Financial Economics 57: 221-245.

http://dx.doi.org/10.1016/s0304-405x(00)00056-8

Liu, M.; Liu, Q.; Ma, T. 2011. The 52-week high momentum strategy in international stock markets, Journal of International Money and Finance 30: 180-204.

http://dx.doi.org/10.1016/j.jimonfin.2010.08.004

Ma, J.; Pagan, J. A.; Chu, Y. 2009. Abnormal returns to mergers and acquisitions in ten Asian stock markets, International Journal of Business 14(3): 235-250.

MacKinlay, A. C. 1997. Event studies in economics and finance, Journal of Economic Literature 35(1): 13-39.

Mandelker, G. 1974. Risk and return: the case of merging firms, Journal of Financial Economics 1(4): 303-335. http://dx.doi.org/10.1016/0304-405x(74)90012-9

Moeller, S.; Schlingemann, F.; Stultz, R. 2005. Wealth destruction on a massive scale? A study of acquiring-firm returns in the recent merger wave, Journal of Finance 60(2): 757-782.

http://dx.doi.org/10.1111/j.1540-6261.2005.00745.x

Morck, R.; Shleifer, A.; Vishny, R. 1990. Do managerial objectives drive bad acquisitions?, Journal of Finance 45(1): 31-48. http://dx.doi.org/10.1111/j.1540-6261.1990.tb05079.x

Pangarkar, N.; Lie, J. R. 2004. Research notes and commentaries: the impact of market cycle on the performance of Singapore acquirers, Strategic Management Journal 25: 1209-1216.

http://dx.doi.org/10.1002/smj.434

Rosenberg, B.; Reid, K.; Lanstein, R. 1985 Persuasive evidence of market inefficiency, Journal of Portfolio Management 11: 9-17. http://dx.doi.org/10.3905/jpm.1985.409007

Rouwenhorst, G. 1999. Local factors and turnover in emerging markets, Journal of Finance 54: 1439-1464.http://dx.doi.org/10.1111/0022-1082.00151

Shah, P.; Arora, P. 2014. M\&A announcements and their effect on return to shareholders: an event study, Accounting and Finance Research 3(2): 170-190. http://dx.doi.org/10.5430/afr.v3n2p170 
Sharpe, W. F. 1964. Capital asset prices: a theory of market equilibrium under conditions of risk, Journal of Finance 19: 425-442. http://dx.doi.org/10.2307/2977928

Shleifer, A.; Vishny, R. 2003. Stock market driven acquisitions, Journal of Financial Economics 70: 295-311. http://dx.doi.org/10.1016/s0304-405x(03)00211-3

Stafford, M. 2012. The short and long term effects of large takeovers on the share price performance of acquiring companies listed on the JSA, Working paper [online]. Available from Internet: http://upetd.up.ac.za/thesis/available/etd-03092013-155546/unrestricted/dissertation.pdf

Stattman, D. 1980, Book values and stock returns, Journal of Selected Papers 4: 25-45.

Uzunski, P. 2011. The Impact on acquirers of domestic and cross-border $M \& A$, involving targets from Central and Eastern Europe, Working paper [online]. Available from Internet: http://pure. au.dk/portal-asb-student/files/36862499/Report.pdf

Vaziri, M. T. 2011. Stock price reaction to acquisitions in banking sector: an empirical analysis on selected Asia Pacific countries, Journal of America Academy of Business 17: 51-61.

Waszczuk, A. 2013. A risk-based explanations of return patterns - evidence from the Polish stock market, Emerging Markets Review 15: 186-210. http://dx.doi.org/10.1016/j.ememar.2012.12.002

Waszczuk, A. 2014. Assembling international equity datasets - review of studies on the crosssection of common stock, Working paper. SSRN. http://dx.doi.org/10.2139/ssrn.2427622.

Wong, A.; Cheung, K. Y. 2009. The effects of merger and acquisition announcements on the security prices of bidding firms and target firms in Asia, International Journal of Economics and Finance 1(2): 274-283. http://dx.doi.org/10.5539/ijef.v1n2p274

Zaremba, A. 2015. Value, size, momentum, and unique role of microcaps in CEE market stock returns, Eastern European Economics 53(3): 221-241.

http://dx.doi.org/10.1080/00128775.2015.1034059

Zaremba, A.; Konieczka, P. 2015. Are value, size and momentum premiums in CEE emerging markets only illusionary?, Finance a úvěr - Czech Journal of Economics and Finance 65(1): 84-104.

Adam ZAREMBA is Professor of Finance at the Department of Investment and Capital Markets of the Poznan University of Economics (Poland). He received his PhD in Finance from Poznan University of Economics (UK). His research focuses on investments, asset pricing, commodities, and financial markets.

Michal PLOTNICKI is PhD candidate at the Collegium of World Economy of the Warsaw School of Economics. His research focuses on financial markets, mainly mergers and acquisitions, and public offerings. 